\title{
IN VITRO ANTIOXIDANT AND ANTIMICROBIAL ACTIVITY OF PHOENIX PUSILLA ROOT EXTRACT
}

\author{
VIJAYA BHARATHI $\mathbf{S}^{1 *}$, ANURADHA $\mathrm{V}^{2}$, RUBALAKSHMI G ${ }^{3}$ \\ ${ }^{1}$ Department of Biotechnology, Faculty of Science and Humanities, SRM Institute of Science and Technology, Chennai - 603 203, Tamil \\ Nadu, India. ${ }^{2}$ Department of Biochemistry, Mohammed Sathak College of Arts \& Science, Chennai - 600 119, Tamil Nadu, India. ${ }^{3}$ GRD \\ Research and Sri Agasthiya GRD Trust, Namakkal - 637 401, Tamil Nadu, India. Email: shavisa04@gmail.com
}

Received: 07 October 2017, Revised and Accepted: 09 November 2017

ABSTRACT

Objective: The objective of this study was to analyze the bioactive compound presence, in vitro antioxidant and antimicrobial potential of Phoenix pusilla root extract.

Methods: Extracts were prepared with ethanol, acetone, and hexane by Soxhlet method. Then, the extracts were checked for phytochemicals presence or absence. In vitro antioxidant activity was analyzed by checking its scavenging ability and reducing property. Antibacterial was assayed by well diffusion method and antifungal activity using sabouraud dextrose broth.

Results: The results showed that the ethanolic root extract contains alkaloids, flavonoids, saponin, tannin, and triterpenoids have potent antioxidant activity and inhibitory activity against certain Gram-positive, Gram-negative, and fungi.

Conclusion: The present study revealed the significance of the plant as a drug. Further, in vivo study is needed to be used as curative agent for different health illness.

Keywords: Phoenix pusilla, Phytochemicals, Ethanol extract, Antioxidant potential.

(C) 2018 The Authors. Published by Innovare Academic Sciences Pvt Ltd. This is an open access article under the CC BY license (http://creativecommons. org/licenses/by/4. 0/) DOI: http://dx.doi.org/10.22159/ajpcr.2018.v11i2.22965

\section{INTRODUCTION}

Nowadays, secondary metabolites such as alkaloids, glycosides, resins, volatile oils, gums, and tannins of medicinal plants are the chemical compounds which are utilized to develop drugs [1,2]. Dietary intake of antioxidants can improve the protection against free radicals. Antioxidants are substances that can prevent the damage caused by reactive oxygen species [3]. Various studies revealed that the presence of phenolic compounds shows antioxidant activity. Phenolic compounds are found to have reducing activity, metal chelating properties, and a hydrogen donor function [4].

Phoenix pusilla (PP) is a dioecious plant, belongs to Arecaceae family found to propagate through seeds. Arecaceae, the palm family, is a monophyletic group, including 183 genera and 2364 species. At present, most palms are distributed in the tropics with a few species reaching subtropical areas. Arecaceae is composed by five strongly supported subfamilies: Arecoideae, Calamoideae, Ceroxyloideae, Coryphoideae, and Nypoideae with Calamoideae as sister group to the rest of the palms and Nypoideae as the next branch [5]. Various ethnobotanical surveys prove the existence of PP in Sri Lanka and South India [6]. Leaves, fruits, and roots of PP are found to have medicinal importance. Roots are utilized in asthma and bronchitis treatment [7]. Nucleated succession study of PP reveals that it cools the soil as well as found to decrease the radiation and so it was identified as better nurse plant to improve the biodiversity conservation [8]. In this present study, the bioactive compounds and in vitro antioxidant, antimicrobial ability of PP root extracts were analyzed. This is the first report on PP root. Hence, far only the unripe fruits of this plant were studied for its therapeutic value.

\section{METHODS}

\section{Plant collection}

The roots of PP were collected in January from Veeramangudi village, Thanjavur District. The collected plant material was authenticated by
Prof. Jayaraman, PARC/2017/3396. The collected plant material was washed thoroughly and shade dried. The dried materials were then powdered and used for extraction.

\section{Extraction}

$50 \mathrm{~g}$ of dried PP root powder was extracted with ethanol (PPE), acetone (PPA), and hexane (PPH) by Soxhlet method for $12 \mathrm{~h}$. The extracts were evaporated, concentrated, and stored.

Phytochemical analysis

Extracts were analyzed for bioactive compounds by standard procedure [9].

\section{Antioxidant assay}

PPE, PPA, and PPH were assayed for antioxidant potential by in vitro methods. All the assays were carried out as triplicate. In all the assay methods, five different concentrations of extracts were analyzed $(100$, $200,300,400$, and $500 \mu \mathrm{g} / \mathrm{ml}$ ).

\section{2, 2-diphenyl-1-picrylhydrazyl (DPPH) radical scavenging assay} The DPPH free radical which is purple in color when reduced to hydrazine changes to yellow. The DPPH assay is based on both electron transfer and hydrogen atom transfer reactions [10]. DPPH (0.1 mM) in ethanol was prepared. Then, $10 \mu \mathrm{l}$ of different extracts of different concentrations were added to $200 \mu \mathrm{l}$ of DPPH solution, ascorbic acid was used as standard and incubated for $30 \mathrm{~min}$, color intensity was read at $517 \mathrm{~nm}[11,12]$

\section{Scavenging of nitric oxide (NO) radical}

At physiological $\mathrm{pH}$, sodium nitroprusside spontaneously generates NO, which interacts with oxygen to produce nitrite ions, which can be estimated by the use of modified Griess-Ilosvay reaction. In the present investigation, Griess-Ilosvay reagent is modified by replacing 1-napthylamine $(5 \%)$ with naphthyl ethylene diamine dihydrochloride 
(NEDD) $(0.1 \% \mathrm{w} / \mathrm{v})$. Nitrite ions react with Griess reagent, which forms a purple azo dye. If the test sample has scavengers the nitrite formation decreases. Nitrite reduction reflects in the reaction sample and the intensity of color was read at $562 \mathrm{~nm}$.

$4 \mathrm{ml}$ of sodium nitroprusside $(10 \mathrm{mM}), 1 \mathrm{ml}$ of phosphate buffer saline ( $\mathrm{pH} 7.4)$, and $1 \mathrm{ml}$ of extract of different concentration or standard solution (rutin) were taken and incubated at $25^{\circ} \mathrm{C}$ for $150 \mathrm{~min}$. After incubation, $0.5 \mathrm{ml}$ of the reaction mixture containing nitrite ion was removed, $1 \mathrm{ml}$ of sulphanilic acid reagent was added, mixed well, and allowed to stand for 5 min for completion of diazotization. Then, $1 \mathrm{ml}$ of NEDD was added, mixed, and allowed to stand for $30 \mathrm{~min}$ in diffused light. Then, the color intensity was read spectrometrically [13].

Scavenging of 2, 2'-azino-bis (3-ethylbezothiazoline-6-sulfonic acid)diammonium salt) (ABTS) radical cation assay

The ABTS generates free radical when it is oxidized with persulfate (blue/green color) which will be reduced by antioxidants in the sample that leads to decolorization [9]. $2 \mathrm{mM}$ ABTS was prepared with $17 \mathrm{mM}$ potassium persulfate and kept in dark before use. The reaction mixture was prepared by pipetting $0.2 \mathrm{ml}$ of various concentrations of the extracts and standard (rutin), $1.0 \mathrm{ml}$ of distilled DMSO, and $0.16 \mathrm{ml}$ of ABTS solution, final volume was made to $1.36 \mathrm{ml}$. Absorbance was measured spectrophotometrically, after $20 \mathrm{~min}$ at $734 \mathrm{~nm}$ [13].

\section{Lipid peroxidation inhibition activity}

Reactive oxygen species may cause lipid peroxidation which leads to the oxidation of biomolecules and results in cellular damage. In this method, $1 \mathrm{ml}$ of egg lecithin, $0.02 \mathrm{ml}$ of ascorbic acid, $0.02 \mathrm{ml}$ of ferric chloride, and $0.1 \mathrm{ml}$ of different concentration of extract, standard were taken and incubated at $37^{\circ} \mathrm{C}(1 \mathrm{~h})$. Then, $2 \mathrm{ml}$ of $15 \%$ trichloroacetic acid and $2 \mathrm{ml}$ of $0.37 \%$ thiobarbituric acid were added and boiled for $15 \mathrm{~min}$, cooled, centrifuged, and absorbance of the supernatant was measured at $532 \mathrm{~nm}[14]$

\section{Antibacterial activity}

Antibacterial activity was determined using agar well diffusion method. The in vitro antibacterial activity of the ethanolic root extract was compared with the standard antibiotic levofloxacin $(10 \mathrm{mg} / \mathrm{ml})$. The bacterial culture (Gram-positive, Gram-negative) was swabbed on the Mueller-Hinton Agar. Using well cutter, five wells (for four different concentration of test sample and positive control) were made in those plates at require distance. $50 \mu \mathrm{l}$ of test sample $(25,50,75$, and $100 \mathrm{mg} / \mathrm{ml}$ ) were added into the test well, levofloxacin disc was added to the center well. Then, the plates were kept in the incubator and incubated at $37^{\circ} \mathrm{C}$ for overnight. After overnight incubation, the plates were checked for inhibition zones and its diameter ( $\mathrm{mm}$ ) was measured [15].

\section{Antifungal screening}

In this antifungal screening, the strains used were grown in the sabouraud dextrose broth and the OD was adjusted $(600 \mathrm{~nm})$ by dilution for proper growth. Then, the sabouraud dextrose agar plates were prepared by pouring $20 \mathrm{ml}$ of the same. In the plate wells were made, and $50 \mu \mathrm{l}$ of the different concentration plant extract (ethanol extract), fluconazole (positive control) were added to the respective wells. The plates were then incubated at $27^{\circ} \mathrm{C}$ for $48 \mathrm{~h}[16]$

\section{RESULTS AND DISCUSSION}

Various root extracts of PP, phytochemical analysis revealed that the ethanolic extract showed the maximum secondary metabolites presence when compared with acetone and hexane extracts. PPE showed the presence of alkaloids, flavonoids, triterpenoids, saponin, tannin, phenolic compounds, glycosides, and primary metabolite like carbohydrates (Table 1).

All the three extracts showed the presence of flavonoids and tannin, whereas the steroids existence was identified only in the hexane extract. Like ethanol extract, PPA showed phenolic compound and saponin presence. Flavonoids are found to have antioxidant, antibacterial,

Table 1: Phytochemical analysis of Phoenix pusilla root extracts

\begin{tabular}{lllll}
\hline S. No. & Compounds & $\begin{array}{l}\text { Ethanolic } \\
\text { extract }\end{array}$ & $\begin{array}{l}\text { Acetone } \\
\text { extract }\end{array}$ & $\begin{array}{l}\text { Hexane } \\
\text { extract }\end{array}$ \\
\hline 1 & Alkaloid & + & - & - \\
2 & Flavonoid & +++ & + & + \\
3 & Triterpenoid & + & - & - \\
4 & Phenolic compound & ++ & + & - \\
5 & Protein & - & - & - \\
6 & Carbohydrates & +++ & - & - \\
7 & Saponin & +++ & ++ & - \\
8 & Steroids & - & - & +++ \\
9 & Glycosides & + & - & - \\
10 & Amino acid & - & - & - \\
11 & Tannin & + & + & + \\
12 & Oil & - & - & - \\
13 & Gums and mucilage & - & - & - \\
14 & Chlorogenic compound & - & - & - \\
\hline
\end{tabular}

+: Less, ++: Moderate, +++: High, -: Negative

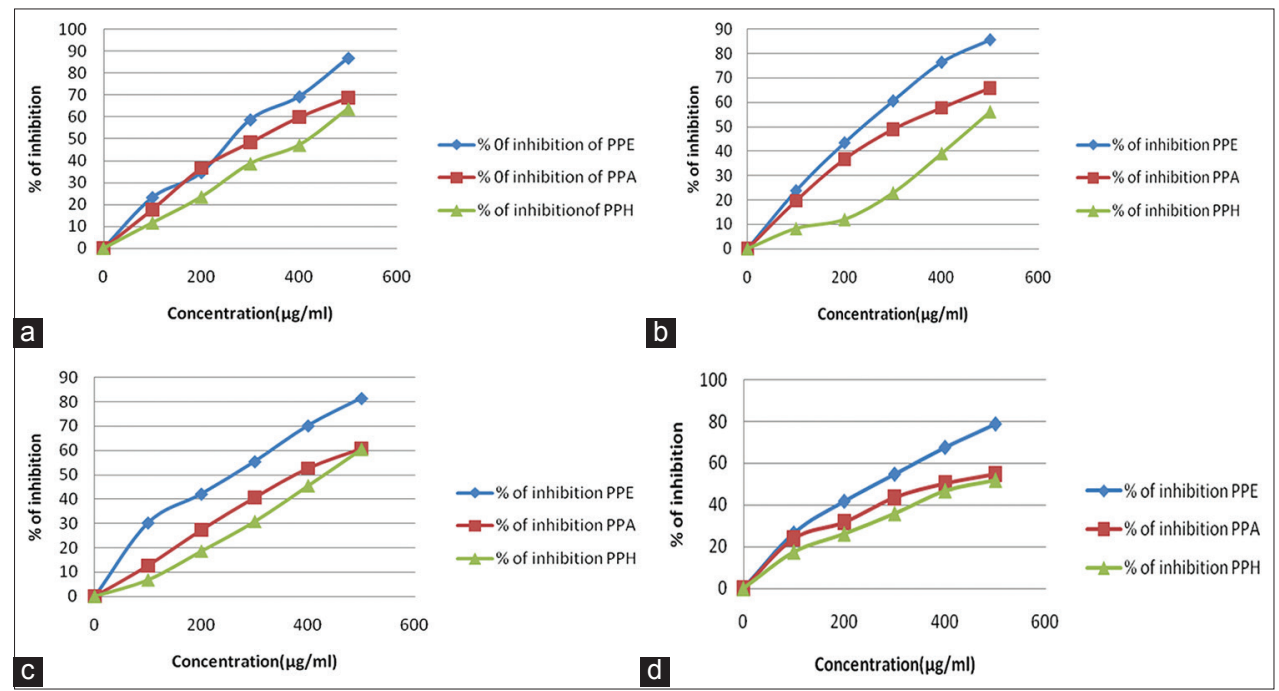

Graph 1: (a-d) Antioxidant potential of different extracts of Phoenix pusilla root (a. DPPH method, b. ABTS method, c. Nitric oxide method, d. Lipid peroxidation inhibition method) 
antiviral, anticancer, and anti-inflammatory activity [17,18]. Apart from having activities similar to flavonoids, tannin also utilized for immediate relief of sore throats, diarrhea, dysentery, hemorrhaging, fatigue, and skin ulcers [19]. Tannin is used as an ingredient in most of the Ayurveda, Siddha, and Unani formulations such as Churna, Rasa, Bhasma, and Khurs [20]. Saponin has commercial application in food, cosmetics, agriculture, and pharmaceutical industries [21]. In vitro antioxidant assay showed that the ethanol extract possesses potential scavenging property than the other two extracts (Graph 1). In DPPH assay, PPE showed $86.9 \pm 6.8 \%$ which is comparatively higher than PPA and PPH. Similarly, the reducing power of iron and scavenging activity of NO, ABTS, lipid peroxide was high in PPE. IC50 calculation represents that the concentration of extract needed for $50 \%$ inhibition was less for ABTS $(260 \mu \mathrm{g} / \mathrm{ml})$, NO scavenging assay $(272 \mu \mathrm{g} / \mathrm{ml})$, followed by DPPH $(277.56 \mu \mathrm{g} / \mathrm{ml})$, and LPI $(284 \mu \mathrm{g} / \mathrm{ml})$ assay. Ascorbic acid was used as a standard in DPPH and LPI method, whereas rutin as standard in ABTS and NO scavenging method. Non-enzymatic antioxidants such as flavonoids, phenolics, tannins, and carotenoids presence may be the reason for antioxidant activity $[22,23]$. Flavonoids and tannin presence in all the three extracts might be the ground for the activity against the free radicals. The existing scientific proof reveals that the tannins can be used as a food additive [24]. Hence, the future study has to focus on isolating the tannin, analyzing its free radical scavenging potential and can be used as food additive.

Among the 5 Gram-positive bacteria assayed, Enterococcus faecalis showed maximum zone of inhibition with $19 \mathrm{~mm}$ (Graph 2), whereas Gram-negative bacteria such as Escherichia coli, Serratia marcescens showed the same value of inhibition at the concentration of $100 \mathrm{mg} \mathrm{ml}$ (Graph 3). Antifungal assay showed that the Candida albicans $(16 \mathrm{~mm}$ ) was more susceptible to ethanol extract of PP (Graph 4).

In this antimicrobial assay, the zone of inhibition was found to dosedependent. The compounds responsible for antimicrobial activity have to be isolated which may reduce the doses of extract used as antimicrobial agent [16].

Statistical analysis by $\mathrm{t}$ test $(\mathrm{n}=3)$ using mean \pm SEM revealed that the $\mathrm{p}<0.05$, so the obtained result was considered as statistically significant.

\section{CONCLUSION}

Present finding reveals that this plant is enriched with therapeutic value. Since PP root extracts exhibited better antioxidant, antimicrobial

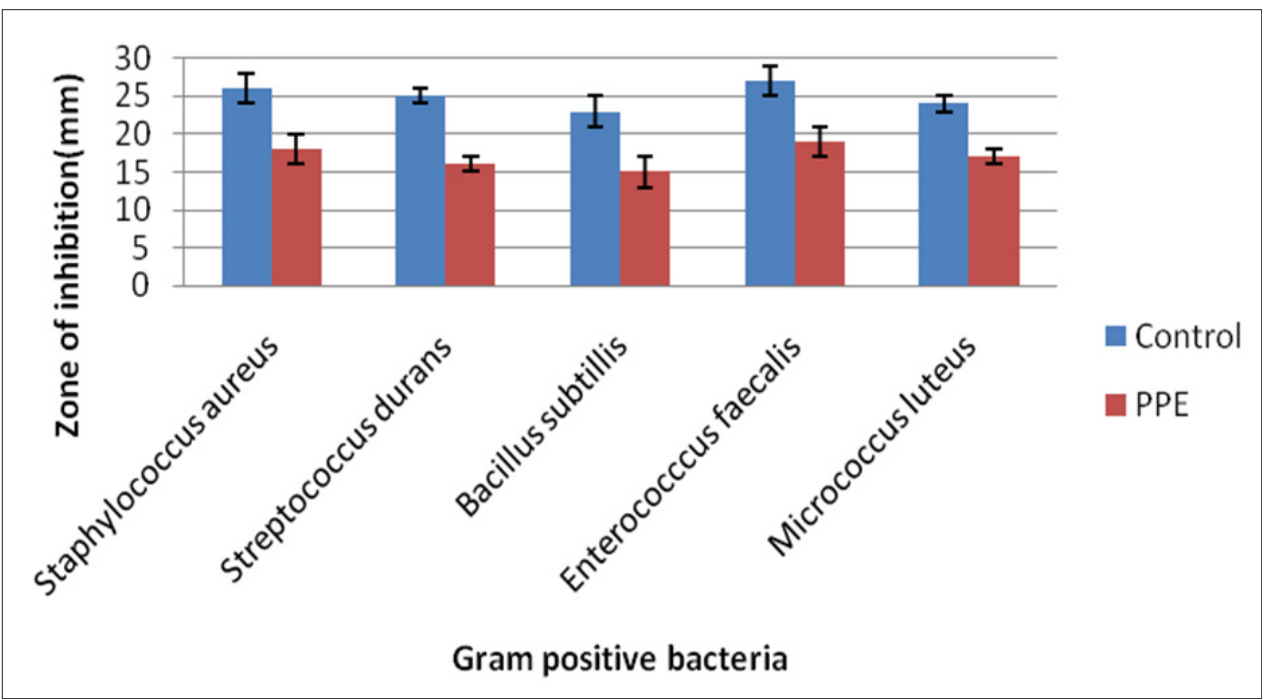

Graph 2: Zone of inhibition of Phoenix pusilla ethanol root extract against Gram-positive bacteria

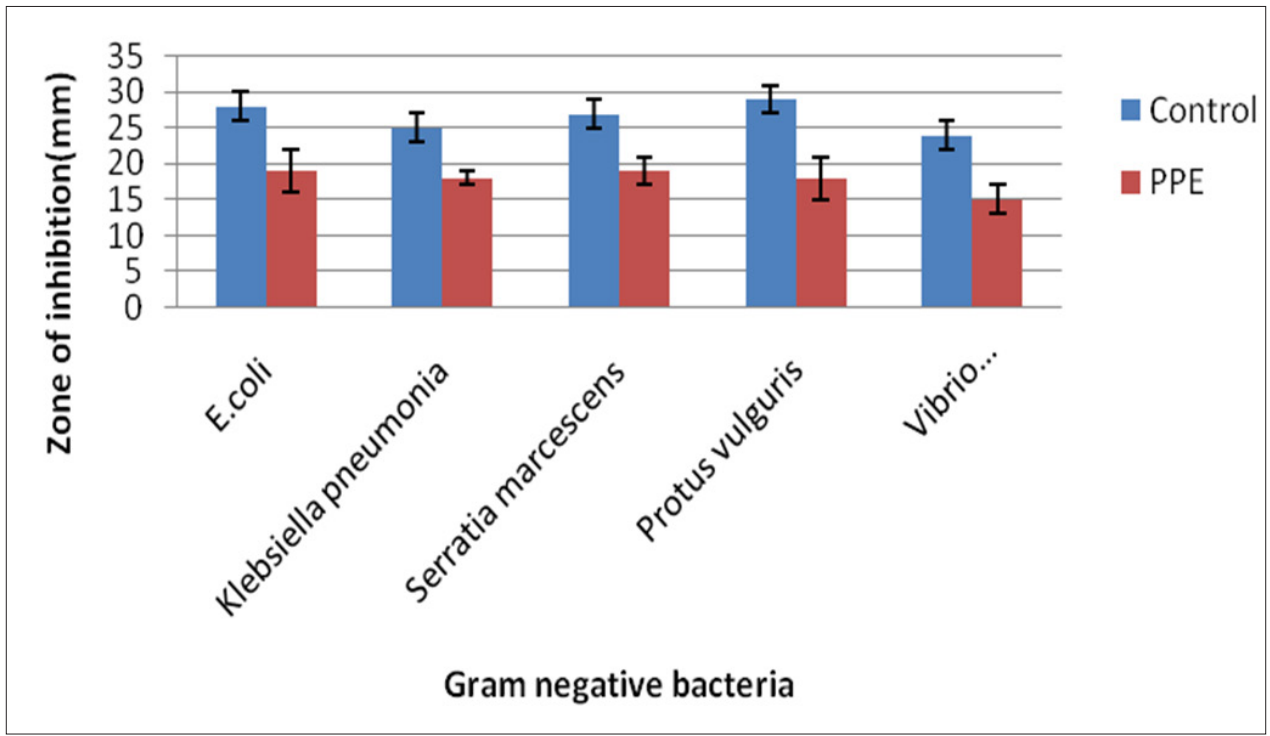

Graph 3: Zone of inhibition of Phoenix pusilla ethanol root extract against Gram-negative bacteria 


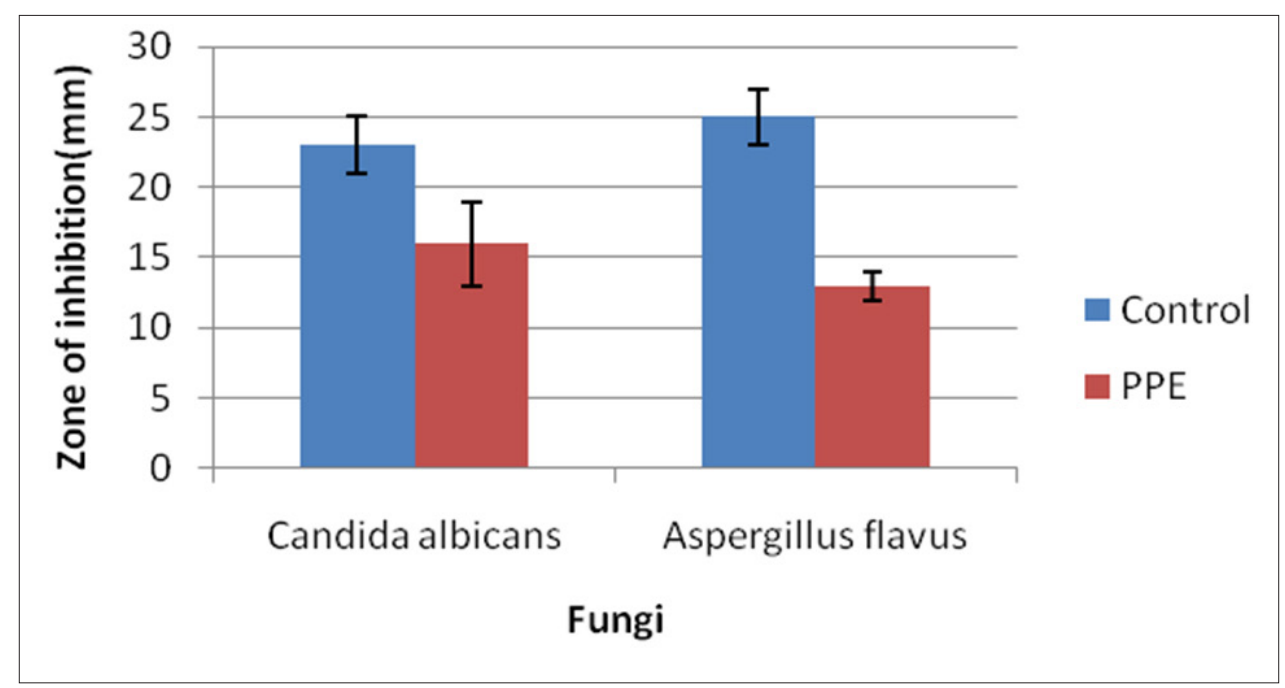

Graph 4: Zone of inhibition of Phoenix pusilla ethanol root extract against fungi

activity further study is needed to explore its importance in various diseases treatment and raise the medicinal importance of this plant to next level.

\section{AUTHORS CONTRIBUTION}

All the authors contributed equally.

\section{CONFLICT OF INTEREST}

There is no conflict of interest.

\section{REFERENCES}

1. Yadav M, Chaterji S, Gupta SK, Watal G. Preliminary phytochemical screening of six medicinal plants used in traditional medicine. Int J Pharm Pharm Sci 2014;6:539-42.

2. Florence AR, Sukumaran S, Joselin J, Brintha TS, Jeeva S. Phytochemical screening of selected medicinal plants of the family Lythraceae. Biosci Discov 2015;6:73-82.

3. Wimalasiri GE, Ranasinghe P, Gunaratne DM, Arachchi LP. Antioxidant and anti-diabetic properties of Caryota urens (Kithul) flour. Procedia Food Sci 2016;6:181-5.

4. Limmongkon A, Janhom P, Amthong A, Kawpanuk M, Nopprang P, Poohadsuan J, et al. Antioxidant activity, total phenolic, and resveratrol content in five cultivars of peanut sprouts. Asian Pac J Trop Biomed 2017:7:332-8.

5. Gomez-Navarro C, Jaramillo C, Herrera F, Wing SL, Callejas R. Palms (ARECACEAE) from a Paleocene rainforest of northern Colombia. Am J Bot 2009;96:1300-12.

6. Karthik S, Subramanian M, Ravikumar S, Dhamotharan R. Medicinal plants and their uses: A study of twelve sacred groves in Cuddalore and Villupuram districts, Tamil Nadu, India. Int Educ Res J 2016;2:95-102.

7. Swain SS, Padhy RN. In vitro antibacterial efficacy of plants used by an Indian aboriginal tribe against pathogenic bacteria isolated from clinical samples. J Taibah Univ Med Sci 2015;10:379-90.

8. Kinhal V, Parthasarathy N. Nucleated succession by an endemic palm Phoenix pusilla enhances diversity of woody species in the arid Coromandel Coast of India. AoB Plants 2010;2010:plq007.

9. Evans WC. Trease and Evans Pharmacognosy. $15^{\text {th }}$ ed. London: WB
Sauders Company Ltd.; 2002. p. 230-40.

10. Liang N, Kitts DD. Antioxidant property of coffee components: Assessment of methods that define mechanisms of action. Molecules 2014;19:19180-208

11. Ebrahimzadeh MA, Nabavi SF, Nabavi SM. Antioxidant activities of methanol extract of Sambucusebulus L. flower. Pak J Biol Sci 2009; $12: 447-50$

12. Rajan S, Gokila M, Jency P, Brindha P, Sujatha RK. Antioxidant and phytochemical properties of Aegle marmelos fruit pulp. Int J Curr Pharm Res 2011;3:65-70

13. Nenadis N, Wang LF, Tsimidou M, Zhang HY. Estimation of scavenging activity of phenolic compounds using the $\operatorname{ABTS}\left({ }^{*}+\right)$ assay. J Agric Food Chem 2004;52:4669-74

14. Jyothi Y, Sangeetha D, Kumar KK. Phytochemical screening and in vitro antioxidant activity of Limnathemum indicum. Res J Pharm Biol Chem Sci 2015;6:791-7.

15. Naz R, Bano A. Antimicrobial potential of Ricinus communis leaf extracts in different solvents against pathogenic bacterial and fungal strains. Asian Pac J Trop Biomed 2012;2:944-7.

16. Erturk O. Antibacterial and antifungal activity of ethanolic extracts from eleven spice plants. Biol Bratisl 2006;61:275-8.

17. Kumar S, Pandey AK. Chemistry and biological activities of flavonoids: An overview. Sci World J 2013;2013:1-16.

18. Goveas SW, Abraham A. Evaluation of antimicrobial and antioxidant activity of stem and leaf extracts of Coscinium fenestratum. Asian J Pharm Clin Res 2013;6:218-27.

19. Ashok PK, Upadhyaya K. Tannins are astringent. J Pharmacogn Phytochem 2012;1:45-50.

20. Ramakrishnan K, Krishnan MR. Tannin-classification, analysis and applications. Anc Sci Life 1994;13:232-8.

21. Mazza G. Saponins: Properties, applications and processing. Crit Rev Food Sci Nutr 2007;47:231-58

22. Kasote DM, Katyare SS, Hegde MV, Bae H. Significance of antioxidant potential of plants and its relevance to therapeutic applications. Int $\mathrm{J}$ Biol Sci 2015;11:982-91

23. Zahin M, Aqil F, Ahmad I. The in vitro antioxidant activity and total phenolic content of four Indian medicinal plants. Int J Pharm Pharm Sci 2009; $1: 88-95$

24. Gulcin I, Huyut Z, Elmastas M, Aboul-Enein HY. Radical scavenging and antioxidant activity of tannic acid. Arab J Chem 2010;3:43-53. 